\title{
Antibiotic release and antibacterial efficacy in cement spacers and cement beads impregnated with different techniques: In vitro study
}

\author{
Farklı yöntemlerle hazırlanan boşluk doldurucu ve çimento boncuklarının \\ antibiyotik salınımı ve antibakteriyel etkinliği: In vitro çalışma
}

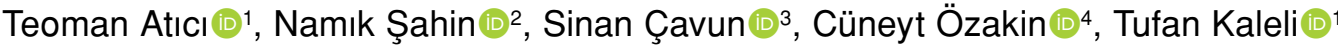 \\ ${ }^{1}$ Department of Orthopedics and Traumatology, Uludag University, Faculty of Medicine, Bursa, Turkey \\ 2Department of Orthopedics and Traumatology, Konya Training and Research Hospital, Konya, Turkey \\ ${ }^{3}$ Department of Medical Pharmacology, Uludag University, Faculty of Medicine, Bursa, Turkey \\ ${ }^{4}$ Department of Medical Microbiology, Uludag University, Faculty of Medicine, Bursa, Turkey
}

\begin{abstract}
Objectives: This study aims to compare the antibiotic release and biological effectiveness of bead type and articulating spacers of different cement types with antibiotics added at alternative phases of cement preparation.

Materials and methods: Four gram vancomycin was added into two types of antibiotic-free cement $\left(\right.$ Simplex ${ }^{\circledR}$, Biomet ${ }^{\circledR}$ ) with similar viscosity and also gentamycin-containing cement $\left(\right.$ Refobacin $\left.{ }^{\circledR}\right)$. Prepared specimens were used to create cement beads and articulating hip spacers, making a total of six different groups. Two alternative groups were formed by adding the Vancomycin while the cement was in dough phase. Antibiotic release and biological activity were evaluated with immunoassay techniques and agar-disk diffusion methods.

Results: All groups showed initial antibiotics surge in the first week, which was 2 to 4 times more evident in the beads group. Antibiotic release and change in release rate were significantly different between Simplexalternative and Simplex, Biomet, Refobacin-beads, and between Biometspacer and Refobacin-beads groups $(\mathrm{p}<0.05)$. Elution of antibiotics was not different between mobile spacers prepared with conventional or alternative methods $(\mathrm{p}>0.05)$. Biomet cement showed larger diffusion inhibition zone in agar. There was no difference between biological activity of the bead and mobile designs of the Biomet brand $(\mathrm{p}>0.05)$. Inhibition zone analyses of agar and disk diffusion tests revealed significant differences between several groups $(\mathrm{p}<0.05)$.

Conclusion: Cement beads provide superior antibiotic release regardless of cement type or preparation method. Simplex $\mathrm{P}^{\circledR}$ cement has lower anti-bacterial efficiency than Biomet ${ }^{\circledR}$. Different methods for cement and antibiotics mixing and addition of extra vancomycin into the commercially drug loaded cement do not have any effect on the results.
\end{abstract}

Keywords: Antibiotic elution; bone cement; infected arthroplasty; spacer.
ÖZ

Amaç: Bu çalışmada çeşitli kemik çimentolarına farklı evrelerde eklenen antibiyotiklerle hazırlanan boncuk tipli ve eklem boşluk dolduruculardan antibiyotik salınımı ve biyolojik etkinliği karşılaştırıldı.

Gereç ve yöntemler: Benzer viskoziteye sahip iki tip antibiyotiksiz çimentoya $\left(\right.$ Simplex ${ }^{\circledR}$, Biomet ${ }^{\circledR}$ ) ve gentamisin içeren çimentoya $\left(\right.$ Refobacin $\left.{ }^{\circledR}\right) 4$ gram vankomisin ilave edildi. Çimento boncuklarını ve kalça boşluk doldurucularını oluşturmak için hazırlanan örneklerden toplam altı farklı grup oluşturuldu. Çimento hamur fazında iken vankomisin eklenerek de iki alternatif grup oluşturuldu. Antibiyotik salınımı ve biyolojik aktivite immunoassay teknikleri ve agar-disk difüzyon yöntemleri ile değerlendirildi.

Bulgular: Boncuk grubunda 2-4 kat daha fazla olmak üzere tüm gruplarda ilk haftada hızlı antibiyotik salınımı görüldü. Simplexalternatif ile Simplex, Biomet, Refobacin-zincir ve Biomet-boşluk doldurucu ile Refobacin-zincir grupları arasında antibiyotik salınımı ve salınma hızındaki değişim anlamlı olarak farklıydı $(\mathrm{p}<0.05)$. Antibiyotiklerin elüsyonu, konvansiyonel veya alternatif yöntemlerle hazırlanan hareketli boşluk doldurucularda farklı değildi $(\mathrm{p}>0.05)$. Biomet çimento, agarda daha büyük difüzyon inhibisyon bölgesi gösterdi. Biomet çimento ile hazırlanan boncuk ve hareketli boşluk doldurucularda biyolojik etkinlik farkı yoktu ( $p>0.05)$. Agar ve disk difüzyon inhibisyon zonları gruplar arasında anlamlıydı $(\mathrm{p}<0.05)$.

Sonuç: Çimento boncukları, çimento tipine veya hazırlama yöntemine bakılmaksızın daha fazla antibiyotik salınımı sağlamaktadır. Simplex $P^{\circledR}$ çimento Biomet'den daha düşük anti-bakteriyel verime sahiptir. Farklı yöntemlerle ve farklı zamanlarda vankomisin eklenerek ve karıştırılarak hazırlanan materyallerde ve ticari olarak antibiyotik yüklü çimentoda farklı yöntemlerin sonuçlar üzerinde herhangi bir etkisi yoktur.

Anahtar sözcükler: Antibiyotik elüsyonu; kemik çimentosu; enfekte artroplasti; boşluk doldurucu. 
Total joint arthroplasty is among the most successful and frequently performed operations today, hence the term "orthopedic operation of the century". ${ }^{[1,2]}$ The demand for such an acclaimed procedure in alleviating patient symptoms is estimated to increase by over $600 \%$ within the next 20 years. $^{[3]}$ This increase infrequency of operations would be paralleled by a higher number of complications such as serious infection. Although relatively rare, it is a devastating complication for both the patient and the surgeons, and is a major cause of revision surgery. Described by Insall et al. ${ }^{[4]}$ in 1983, two-stage revision arthroplasty using antibiotic impregnated spacers is still the gold standard of treatment for late chronic infections, yielding over $90 \%$ clinical success. ${ }^{[4-10]}$

Antibiotics released from bone cement is effected by several parameters such as type and amount of antibiotics, cement composition, and surface area of the spacer. The exact mechanism of drug elution is also still unclear. ${ }^{[5,7,7,11,12]}$ Heterogeneity of spacer construction methods, material variety, cement and antibiotic type, mixing technique, and postoperative antibiotic therapy make clinical comparison of different spacer types extremely difficult. ${ }^{[7,1]}$ Laboratory studies are far from ideal in modeling the actual biological environment since standardized cement specimens prepared according to biomechanical testing criteria are morphologically different than spacers hand molded by the surgeon during hip replacement surgery.

The purpose of this study is to compare the antibiotics release patterns and antimicrobial activity of different spacer ty pes. The tests will be performed in a standardized testing environment. Our hypothesis is that mobile spacers will yield less antibiotics release compared to bead types because their bulkier architecture will not permit the drug trapped in deep portions of the cement to reach the surface. Determining the effect of drug impregnation time, cement type, antibiotic type, and additional antibiotic enrichment of commercially drug impregnated and non-impregnated cement types in terms of antibiotics release and biological efficiency will be the secondary objectives of this study.

\section{MATERIALS AND METHODS}

Two different brands of bone cement without antibiotics and one type of commercially available antibiotic-impregnated bone cement were used (Simplex ${ }^{\oplus}$ : Howmedica, Limerick, Ireland, BiometPalacos $^{\circledR}$ : Biomet Orthopaedics, Kerzer, Switzerland and Refobacin ${ }^{\circledR}$-Palacos-G: Biomet Orthopaedics, Kerzer, Switzerland). Each spacer prepared from these cements had 4 grams of vancomycin (Vancomax 500 mg. VEM İlaç San. ve Tic. A.Ş., Tekirdağ, Turkey) added before mixing and were molded into either mobile articulating hip spacer (MHS) or cement beads, making up six groups of conventionally prepared spacers: Simplex Bead (SB), Simplex Spacer (SS), Palacos Bead (PB), Palacos Spacer (PS), Palacos Genta Bead (PGB), and Palacos Genta Spacer (PGS). In addition, two more groups were formed, this time preparing the MHS in an alternative fashion by adding the antibiotics powder not before mixing the cement but after the initiation phase while the cement was still in its shapeable doughy form (2-3 minutes); Simplex Alternative (SA) and Palacos Alternative (PA) (Table I). No cement beads were prepared using the alternative antibiotic mixing technique.

\section{Preparation of cement beads and MHS}

Three samples for each group were prepared under sterile ambient laboratory conditions, taking care to maintain controlled temperature and humidity during the procedures. For the cement beads and conventionally prepared MHS groups, vancomycin and polymethyl methacrylate (PMMA) powder were mixed with a commercial mixer for two minutes in order to achieve homogeneity, after which liquid

TABLE I

Groups and materials

\begin{tabular}{|c|c|c|c|c|}
\hline & \multicolumn{3}{|c|}{ Material type } & \multirow[b]{3}{*}{ Total } \\
\hline & \multirow[b]{2}{*}{ Beads (n) } & \multicolumn{2}{|c|}{ Mobil hip spacer } & \\
\hline & & Conventional (n) & Alternative (n) & \\
\hline Simplex (S) & $3(\mathrm{SB})$ & 3 (SS) & $3(\mathrm{SA})$ & 9 \\
\hline Palacos (P) & 3 (PB) & 3 (PS) & $3(\mathrm{PA})$ & 9 \\
\hline Palacos-genta (PG) & 3 (PGB) & 3 (PGS) & - & 6 \\
\hline Total & 9 & 9 & 6 & 24 \\
\hline
\end{tabular}

SB: Simplex bead; SS: Simplex spacer; SA: Simplex alternative; PB: Palacos bead; PS: Palacos spacer; PA: Palacos alternative; PGB: Palacos genta bead; PGS: Palacos genta spacer. 


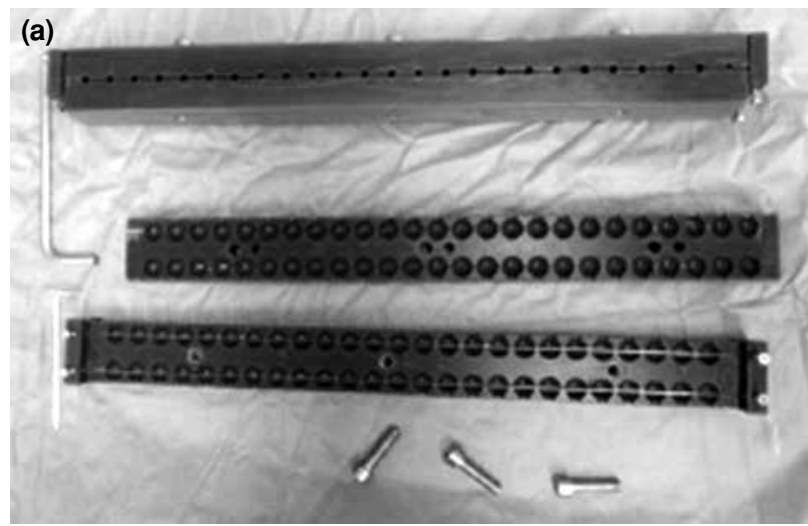

monomer was added. Samples were molded once in dough form. For MHSs prepared in alternative fashion, antibiotics were added after liquid monomer and PMMA powder were mixed and bone cement was in dough form, after which the spacer was molded.

Cement beads were prepared with the method described by DeCoster and Bozgria ${ }^{[13]}$ (Figure 1a, b). Mobile articulating hip spacers were molded using a collar-style stem with a $50 \mathrm{~mm}$ monopolar head as described by several authors (Figure 2). ${ }^{[10,14,15]}$ Cement beads and mobile spacers were prepared with the same amount of cement and antibiotic mixture in order to achieve uniform specimen mass.

The materials were kept in cylindrical glass containers filled with $500 \mathrm{~mL}$ of phosphate buffered saline (PBS) (PBS: $\mathrm{NaCl} 8.76 \mathrm{~g} / \mathrm{L}, \mathrm{K}_{2} \mathrm{HPO}_{4} 0.87 \mathrm{~g} / \mathrm{L}$, $\mathrm{KH}_{2} \mathrm{PO}_{4} 0.68 \mathrm{~g} / \mathrm{L}$ ) and stored in the same laboratory conditions.

\section{Measuring the antibiotics elution}

$3 \times 250 \mu \mathrm{g} / \mathrm{L}$ of the PBS solution from the containers were taken from each sample at certain time points and

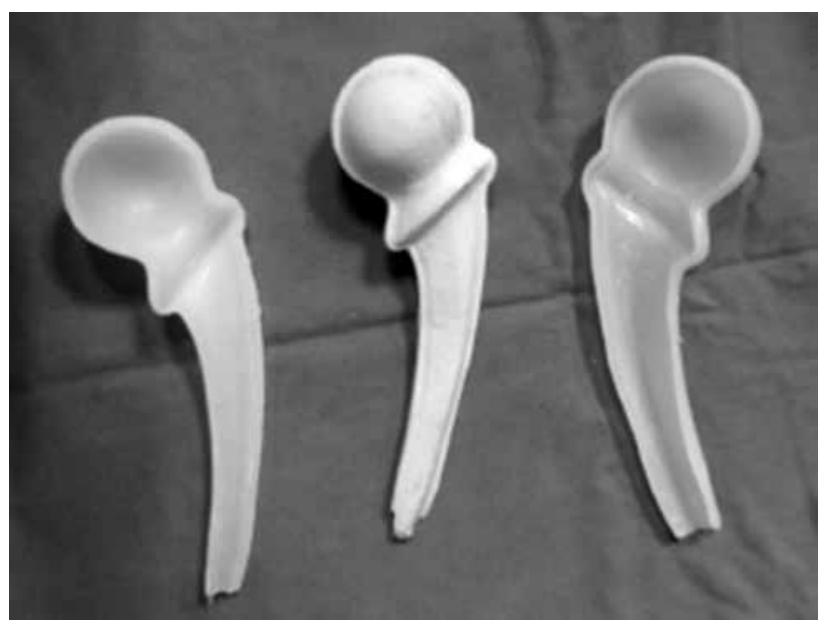

Figure 2. Template for spacer and mobile hip spacer.

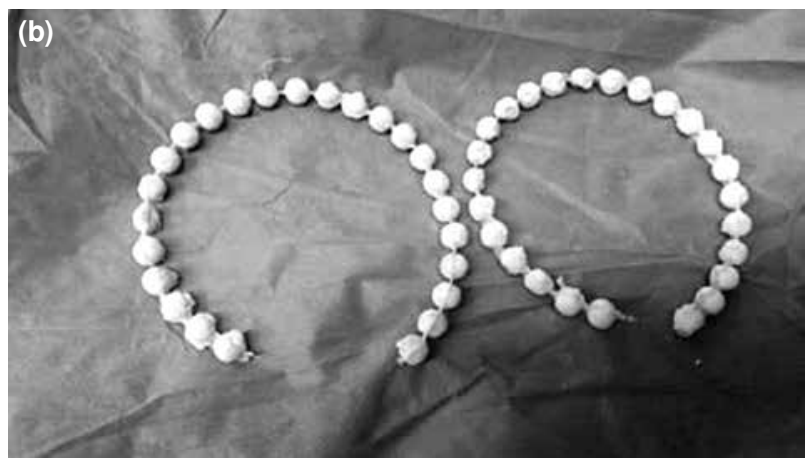

Figure 1. (a) Bone cement bead template. (b) Bone cement beads.

stored at $-20^{\circ}$ for cumulative analysis of vancomycin elution. A total of 16 samples were collected from each specimen $\left(1-7,9,11,13,16,19,23,28,35\right.$, and $42^{\text {nd }}$ day). Antibiotics elution was measured using the PETINIA technique. This in vitro diagnostic test, sometimes referred to as VANC methodology, utilizes synthetic particle-vancomycin conjugate and monoclonal vancomycin-specific antibody. Vancomycin molecules eluted from the cement samples compete with synthetic vancomycin conjugates to attach to monoclonal antibodies, reducing the aggregation rate. Therefore, aggregation rate is inversely proportional to concentration of the eluted antibiotic.

Aggregation rate was measured using bi-chromatic turbid metric readings at 340 and $700 \mathrm{~nm}$. Results are reported as $\mu \mathrm{g} / \mathrm{mL}$.

\section{Testing antibacterial activity}

Biological activity of PBS samples containing the antibiotics eluted from the spacers were tested against Staphylococcus aureus strain sensitive to vancomycin

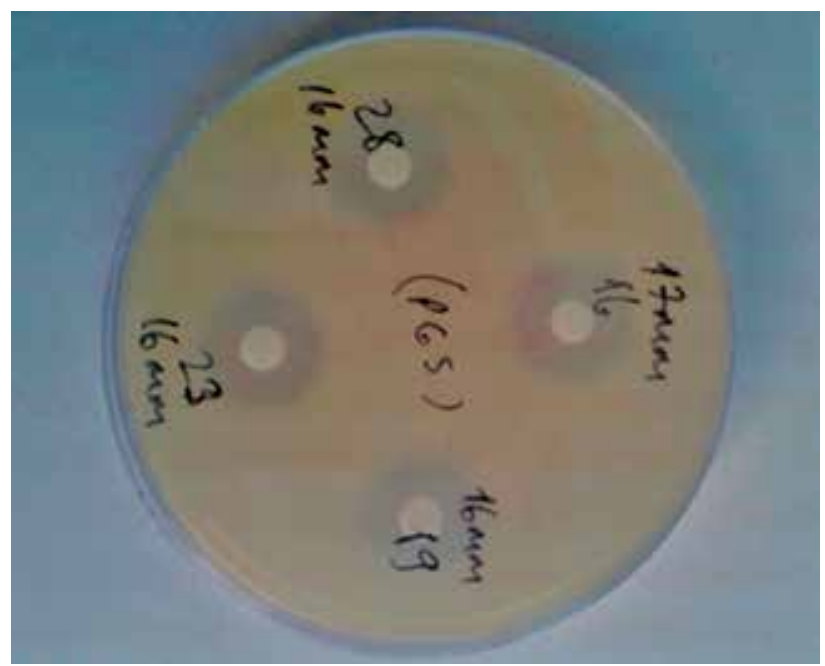

Figure 3. Example of inhibition zone for disc diffusion. 
TABLE II

Amount of antibiotic release, inhibition zone of agar diffusion and inhibition zone for disc diffusion

\begin{tabular}{|c|c|c|c|}
\hline & Antibiotic elution $(\mu \mathrm{g} / \mathrm{mL})$ & Agar diffusion inhibition (mm) & Disc diffusion inhibition (mm) \\
\hline Groups & Mean $\pm S D$ & Mean $\pm S D$ & Mean $\pm S D$ \\
\hline Simplex bead & $272.8 \pm 70.5$ & $17.0 \pm 0.43$ & $13.1 \pm 0.23$ \\
\hline Palacos bead & $277.4 \pm 97.5$ & $20.6 \pm 3.18$ & $16.3 \pm 3.6$ \\
\hline Palacos genta bead & $324.1 \pm 33.8$ & $22.0 \pm 0.57$ & $18.1 \pm 0.66$ \\
\hline Simplex spacer & $58.7 \pm 32.5$ & $12.6 \pm 2.11$ & $9.5 \pm 1.35$ \\
\hline Palacos spacer & $127.0 \pm 60.2$ & $17.1 \pm 1.40$ & $12.8 \pm 1.46$ \\
\hline Palacos genta spacer & $109.5 \pm 16.8$ & $20.2 \pm 1.15$ & $15.6 \pm 1.26$ \\
\hline Simplex alternative & $41.3 \pm 5.2$ & $13.3 \pm 1.08$ & $9.8 \pm 0.36$ \\
\hline Palacos alternative & $181.4 \pm 48.8$ & $18.6 \pm 0.46$ & $14.1 \pm 0.30$ \\
\hline
\end{tabular}

SD: Standard deviation.

with known minimum inhibition concentration values using disc and agar diffusion methods. For the agar method, drug containing PBSs were placed into $6 \mathrm{~mm}$ pits formed within $S$. aureus planted 0.5 McFarland agar. For the disc method, PBS-soaked and dried sterile discs were placed onto $S$. aureus planted 0.5 McFarland agar. Both specimens were kept in an incubator at $35^{\circ} \mathrm{C}$ for 24 hours. Diameter of area with no bacterial growth around the pits and disc were measured (Figure 3). Positive biological activity was defined as presence of an inhibition zone with no bacterial growth.

\section{Statistical analysis}

Statistical analysis was performed with IBM SPSS version 23.0 (IBM Corp., Armonk, NY, USA) software. Results are reported as mean \pm standard deviation (SD). Normal distribution of data was assessed using the Shapiro-Wilk test. One way ANOVA was used for comparison of groups with normal distribution. Tukey test was used for multiple comparison tests. Significance was defined as $\alpha=0.05$.

\section{RESULTS}

All groups showed an initial antibiotics surge in the first week, which rapidly declined in the following week. The burst of antibiotics release in the first week was 2 to 4 times more evident in the beads groups compared to mobile spacer groups. The amount of antibiotic release and inhibition zone diameters of agar and disc diffusion models for each type of cement are given in Table II. Cumulative amount of released antibiotics and change in release rate were significantly lower in the SA group compared to $\mathrm{SB}, \mathrm{PB}$, and PGB groups $(\mathrm{p}<0.05)$. Similarly, PS group showed significantly lower antibiotics elution

TABLE III

Statistical evaluation of antibiotic release

\begin{tabular}{lccc}
\hline & \multicolumn{3}{c}{ Subset for alpha=0.05 } \\
\cline { 2 - 4 } Groups & 1 & 2 & 3 \\
\hline Simplex alternative & 41.3852 & & \\
Simplex spacer & 58.7506 & & \\
Palacos genta spacer & 109.5442 & & \\
Palacos spacer & 127.0073 & 127.0073 & 181.4250 \\
Palacos alternative & 181.4250 & 181.4250 & 272.8750 \\
Simplex bead & & 272.8750 & 277.4765 \\
Palacos bead & & 277.4765 & 324.0833 \\
Palacos genta bead & & & $\mathrm{p}=0.073$ \\
Significantly & $\mathrm{p}<0.05$ & $\mathrm{p}<0.05$ & \\
\hline
\end{tabular}


TABLE IV

Statistical evaluation of inhibition zone for agar diffusion

\begin{tabular}{lcccc}
\hline & \multicolumn{4}{c}{ Subset for alpha=0.05 } \\
\cline { 2 - 5 } Groups & 1 & 2 & 3 & 4 \\
\hline Simplex spacer & 12.6875 & & \\
Simplex alternative & 13.3750 & 13.3750 & \\
Simplex bead & 17.0000 & 17.0000 & 17.0000 \\
Palacos spacer & & 17.1667 & 17.1667 & \\
Palacos alternative & & & 18.6042 & 18.6042 \\
Palacos genta spacer & & & 20.2917 & 20.2917 \\
Palacos bead & & & 20.6250 & 20.6250 \\
Palacos genta bead & & & & 22.0000 \\
Significantly & & & $\mathrm{p}<0.05$ & $\mathrm{p}=0.210$ \\
\hline
\end{tabular}

and change in release rate compared to the PGB group $(\mathrm{p}<0.05)$ (Table III). Elution of antibiotics was not different between mobile spacers prepared with conventional or alternative methods ( $\mathrm{p}>0.05)$ ( 58.7 and $41.3 \mu \mathrm{g} / \mathrm{dL}$ for Simplex, 127.0 and $181.4 \mu \mathrm{g} / \mathrm{dL}$ for Biomet, respectively). When cement brands were compared regardless of spacer design, Biomet cement showed higher antibiotics elution, however this difference was not statistically significant. When antibacterial efficiency was evaluated, Biomet cement showed a larger diffusion inhibition zone in agar (Table IV). There was no significant difference between biological activity of the bead and mobile designs of the Biomet brand $(p>0.05)$. Inter-group analysis revealed that antibacterial efficiency of SS was significantly lower than PS, PA, PGS, PB, and PGB groups in terms of agar diffusion inhibition zone $(\mathrm{p}<0.05)$. Similarly, SA had lower activity compared to PA, PGS, PB, and
PGB groups, and SB was inferior to PGB $(\mathrm{p}<0.05)$. Inhibition zone analyses using disk diffusion tests further confirmed that SS were biologically less active than PA, PGS, PB, and PGB $(\mathrm{p}<0.05)$. Similarly, the $S A$ group had smaller disc diffusion inhibition zones than PGS, PB, and PGB groups $(\mathrm{p}<0.05)$ and $\mathrm{PB}$ was inferior to PGB $(\mathrm{p}<0.05)$ (Table V).

\section{DISCUSSION}

The main purpose of this study was to compare the antibiotic release quantity of hand-made PMMA beads and hand-made articulating hip spacers. The secondary objective was to evaluate whether alternative methods for mixing the antibiotics-loaded spacer would improve antibiotics release or not. Our results revealed that bead type spacers provided 2-4 times higher drug elution for a significantly longer period of time. This is in accordance with the majority

TABLE V

Statistical evaluation of inhibition zone for disc diffusion

\begin{tabular}{lcccc}
\hline & \multicolumn{4}{c}{ Subset for alpha=0.05 } \\
\cline { 2 - 5 } Groups & 1 & 2 & 3 & 4 \\
\hline Simplex spacer & 9.5000 & & & \\
Simplex alternative & 9.8542 & 9.8542 & & \\
Palacos spacer & 12.8125 & 12.8125 & 12.8125 \\
Simplex bead & 13.1042 & 13.1042 & 13.1042 & \\
Palacos alternative & & 14.1042 & 14.1042 & 14.1042 \\
Palacos genta spacer & & & 15.6042 & 15.6042 \\
Palacos bead & & & 16.3333 & 16.3333 \\
Palacos genta bead & & & & 18.1042 \\
Significantly & $\mathrm{p}<0.05$ & $\mathrm{p}<0.05$ & $\mathrm{p}<0.05$ & $\mathrm{p}=0.089$ \\
\hline
\end{tabular}


of the literature reporting superior drug release with bead shaped cement. However, our results failed to detect any improvement in biological activity with alternative cement mixing techniques.

The gold standard of treatment for periprosthetic infection is removal of the prosthesis and delivery of high dose local antibiotics combined with parenteral antibiotherapy. Antibiotic-loaded bone cement has been the primary method of local drug administration for over four decades. Antibiotic release from bone cement molded as beads is reported to be substantially higher when compared to spacers resembling joint architecture. Even though higher local antibiotics concentrations are achieved by using cement beads as in studies by Anagnostakos et al. ${ }^{[16]}$ and Moojen et al., ${ }^{[14]}$ clinical implication of this difference is questionable. Hsieh et al. ${ }^{[10]}$ reported that recurrent infection rates were similar with both types of cement design.

Whether static or articulating, both types of joint spacers are commonly used, and they are either prepared during surgery by hand-molding or toolmolding, or they are commercially available. Handmade spacers have been in clinical practice for over two decades with good clinical results. ${ }^{[4,9,10,17,18]}$ Articulating spacers are relatively new, and large scale randomized studies on their efficiency at eradicating periprosthetic infection are missing. ${ }^{[7,9,10]}$ A small number of case studies report equivocal infection eradication rates. ${ }^{[5,16,19]}$ Hand molded spacers are easy to prepare and have low cost, however, their varying sizes and shapes make standardized laboratory assessment difficult. Tool molded spacers (bead or articulating) are more uniform, as with commercially available designs, and provide homogeneity in comparative studies. Several techniques are described in the preparation of these products. ${ }^{[5,7,10,14,16,20]}$

The ideal antibiotic impregnation technique for optimum drug elution from bone cement is controversial. While some authors favor commercially available antibiotics-impregnated bone cement over manual mixing during surgery, others advocate that manual mixing increases cement porosity, hence more effective drug release. . $5,7,14,17,21]$ The main disadvantage of manual mixing is that it is difficult to achieve homogenous distribution of antibiotic powder in the cement. ${ }^{[16]}$ On the other hand, limited drug concentration in commercially available antibiotics-impregnated cement is of concern for effective antibacterial activity. Strict criteria set by national and international registrations prevent/ ban fabrication of bone cement with high doses of antibiotics. Walenkamp ${ }^{[22]}$ pointed out that Western countries gradually adapted to the antibiotic loading protocols described initially in developing countries. The goal of periprosthetic infection treatment is total eradication of microorganisms, and achieving high levels of local drug concentration is crucial. Adding the desired amount of antibiotics into the bone cement during surgery serves this purpose and provides high doses of local antibiotics. ${ }^{[7,14,15,23]}$

The standard procedure for antibiotics impregnation is to first add antibiotic powder into the polymer form of the cement, and then to mix the prepared powder with liquid monomer. Hanssen and Spangeh ${ }^{[17]}$ described a modification of this procedure in their technical note in 2004. They preferred to mix powder and liquid monomer first, and then introduce the antibiotics powder during the dough phase of bone cement. They stated that crystallization caused by addition of the drug increased cement porosity and enhanced antibiotic clearance. However, this method of antibiotic impregnated cement preparation is rarely used and clinical evidence for its efficacy is missing. The sole in vitro study of this technique was conducted by Shiramizu et al. ${ }^{[2]}$ who have concluded that the Hanssen method may be preferable for introduction of large doses of antibiotics. Miller et al. ${ }^{[25]}$ tested the Hanssen method by mixing 10 grams of vancomycin during the dough phase and reported higher drug concentrations when compared to other methods. We did not find any increase in drug elution in articulating hip spacers prepared with the Hannsen method. Our study design was different in that we used lower doses of vancomycin and the spacer was molded as a collarless stem that could be used as an articulating hip spacer, rather than $6 \times 12.7 \mathrm{~mm}$ cylinder shaped spacer models used in the aforementioned studies. These cylinders are constructed to be in accordance with the ASTM (American Society for Testing and Material Standards) F451 criteria which are set especially for compressive biomechanical testing. We believe that ours is a better model of the actual clinical environment, in terms of both drug concentration and surface area.

CMW 3 (DePuy, Blackpool, UK), Simplex P (Howmedica, Limerick, Ireland), and Palacos (Heraeus Medical, Wehreim, Germany) have different powder and liquid constituents and viscosity and are frequently used in clinical practice and studies. Palacos is known to exhibit more efficient antibiotics elution compared to other cement types. ${ }^{[7,926-28]}$ Tabromycin and vancomycin release is documented to be significantly higher with Palacos compared to CMW 1 and CMW 3.[27] There is no such established difference between Simplex $\mathrm{P}$ and 
CMW 3. When analyzed in terms of antimicrobial activity, higher drug concentrations achieved with Palacos fail to elicit enhanced efficacy. ${ }^{[21,29-34]}$ In contrast to the aforementioned studies, our results yielded similar drug concentrations with Palacos, CMW 3, and Simplex P. Despite the similar antibiotics concentrations, samples from Simplex P showed lower antibacterial activity. Decreased antibacterial activity from similar drug concentrations may be due the effect of different levels of heat generated during exothermic reaction of the drug molecule, or due to imprecise semi-quantitative methods for analyzing drug activity.

There are several limitations to his study, of which in vitro design of the experiment is the most significant. The actual clinical environment contains several hostrelated factors that effect antibacterial activity, which are not always possible to reproduce in a laboratory set-up. Near a joint space implanted with cement beads or articulating spacers, surrounding fluid volume will be less than $500 \mathrm{~mL}$ as used in laboratory, likely to increase the local drug concentration.

In conclusion, antibiotics release from cement beads is higher than that from articulating hip spacers, regardless of cement type or preparation method. Antibacterial activity of spacer samples prepared from Simplex P brand cement is significantly less compared to Biomet brand, whether it is molded as beads or articulating forms. Different methods for cement and antibiotic mixing and addition of extra vancomycin into the commercially drug loaded cement did not have any effect on the results.

\section{Declaration of conflicting interests}

The authors declared no conflicts of interest with respect to the authorship and/or publication of this article.

\section{Funding}

This work was supported by Scientific Research Project of the University of Uludag (Project no: KUAP (T)- 2012-29).

\section{REFERENCES}

1. Learmonth ID, Young C, Rorabeck C. The operation of the century: total hip replacement. Lancet 2007;370:1508-19.

2. Upadhyay A, York S, Macaulay W, McGrory B, Robbennolt J, Bal BS. Medical malpractice in hip and knee arthroplasty. J Arthroplasty 2007;22(6 Suppl 2):2-7.

3. Kurtz S, Ong K, Lau E, Mowat F, Halpern M. Projections of primary and revision hip and knee arthroplasty in the United States from 2005 to 2030. J Bone Joint Surg [Am] 2007;89:780-5.

4. Insall JN, Thompson FM, Brause BD. Two-stage reimplantation for the salvage of infected total knee arthroplasty.J Bone Joint Surg [Am] 1983;65:1087-98.

5. Cui Q, Mihalko WM, Shields JS, Ries M, Saleh KJ. Antibiotic- impregnated cement spacers for the treatment of infection associated with total hip or knee arthroplasty. J Bone Joint Surg [Am] 2007;89:871-82.

6. Hsieh $\mathrm{PH}$, Chen LH, Chen $\mathrm{CH}$, Lee MS, Yang WE, Shih $\mathrm{CH}$. Two-stage revision hip arthroplasty for infection with a custom-made, antibiotic-loaded, cement prosthesis as an interim spacer. J Trauma 2004;56:1247-52.

7. Jacobs C, Christensen CP, Berend ME. Static and mobile antibiotic-impregnated cement spacers for the management of prosthetic joint infection. J Am Acad Orthop Surg 2009;17:356-68.

8. Garvin KL, Hanssen AD. Infection after total hip arthroplasty. Past, present, and future. J Bone Joint Surg [Am] 1995;77:1576-88.

9. Joseph TN, Chen AL, Di Cesare PE. Use of antibioticimpregnated cement in total joint arthroplasty. J Am Acad Orthop Surg 2003;11:38-47.

10. Hsieh $\mathrm{PH}$, Shih $\mathrm{CH}$, Chang $\mathrm{YH}$, Lee MS, Shih HN, Yang WE. Two-stage revision hip arthroplasty for infection: comparison between the interim use of antibiotic-loaded cement beads and a spacer prosthesis. J Bone Joint Surg [Am] 2004;86:1989-97.

11. Bertazzoni Minelli E1, Benini A, Magnan B, Bartolozzi P. Release of gentamicin and vancomycin from temporary human hip spacers in two-stage revision of infected arthroplasty. J Antimicrob Chemother 2004;53:329-34.

12. van de Belt $H$, Neut $D$, Uges DR, Schenk W, van Horn JR, van der Mei $\mathrm{HC}$, et al. Surface roughness, porosity and wettability of gentamicin-loaded bone cements and their antibiotic release. Biomaterials 2000;21:1981-7.

13. Decoster TA, Bozorgnia S.Antibiotic beads. J Am Acad Orthop Surg 2008;16:674-8.

14. Moojen DJ, Hentenaar B, Charles Vogely H, Verbout AJ, Castelein RM, Dhert WJ. In vitro release of antibiotics from commercial PMMA beads and articulating hip spacers. J Arthroplasty 2008;23:1152-6.

15. Anagnostakos K, Kelm J, Regitz T, Schmitt E, Jung W. In vitro evaluation of antibiotic release from and bacteria growth inhibition by antibiotic-loaded acrylic bone cement spacers. J Biomed Mater Res B Appl Biomater 2005;72:373-8.

16. Anagnostakos K, Wilmes P, Schmitt E, Kelm J. Elution of gentamicin and vancomycin from polymethylmethacrylate beads and hip spacers in vivo. Acta Orthop 2009;80:193-7.

17. Hanssen AD, Spangehl MJ. Practical applications of antibiotic-loaded bone cement for treatment of infected joint replacements. Clin Orthop Relat Res 2004;427:79-85.

18. Durbhakula SM, Czajka J, Fuchs MD, Uhl RL. Spacer endoprosthesis for the treatment of infected total hip arthroplasty. J Arthroplasty 2004;19:760-7.

19. Fehring TK, Odum S, Calton TF, Mason JB. Articulating versus static spacers in revision total knee arthroplasty for sepsis. The Ranawat Award. Clin Orthop Relat Res 2000;380:9-16.

20. Evans RP. Successful treatment of total hip and knee infection with articulating antibiotic components: a modified treatment method. Clin Orthop Relat Res 2004;427:37-46.

21. Kuechle DK, Landon GC, Musher DM, Noble PC. Elution of vancomycin, daptomycin, and amikacin from acrylic bone cement. Clin Orthop Relat Res 1991;264:302-8.

22. Walenkamp GH. Self-mixed antibiotic bone cement: western countries learn from developing countries. Acta Orthop 2009;80:505-7. 
23. Göçer H, Emir D, Önger ME, Dabak N. Effects of bone cement loaded with teicoplanin, $\mathrm{N}$-acetylcysteine or their combination on Staphylococcus aureus biofilm formation: an in vitro study. Eklem Hastalik Cerrahisi 2017;28:13-8.

24. Shiramizu K, Lovric V, Leung AM, Walsh WR. Antibiotic distribution in a bone cement spacer model. Hip Int 2007;17:218-23.

25. Miller R, McLaren A, Leon C, McLemore R. Mixing method affects elution and strength of high-dose ALBC: a pilot study. Clin Orthop Relat Res 2012;470:2677-83.

26. Shiramizu K, Lovric V, Leung A, Walsh WR. How do porosity-inducing techniques affect antibiotic elution from bone cement? An in vitro comparison between hydrogen peroxide and a mechanical mixer. J Orthop Traumatol 2008;9:17-22.

27. Penner MJ, Duncan CP, Masri BA. The in vitro elution characteristics of antibiotic-loaded CMW and Palacos-R bone cements. J Arthroplasty 1999;14:209-14.

28. Trippel SB. Antibiotic-impregnated cement in total joint arthroplasty. J Bone Joint Surg [Am] 1986;68:1297-302.

29. Greene N, Holtom PD, Warren CA, Ressler RL, Shepherd L, McPherson EJ, Patzakis MJ. In vitro elution of tobramycin and vancomycin polymethylmethacrylate beads and spacers from Simplex and Palacos.
Am J Orthop 1998;27:201-5.

30. Gálvez-López R, Peña-Monje A, Antelo-Lorenzo R, Guardia-Olmedo J, Moliz J, Hernández-Quero J, et al. Elution kinetics, antimicrobial activity, and mechanical properties of 11 different antibiotic loaded acrylic bone cement. Diagn Microbiol Infect Dis 2014;78:70-4.

31. Squire MW, Ludwig BJ, Thompson JR, Jagodzinski J, Hall D, Andes D. Premixed antibiotic bone cement: an in vitro comparison of antimicrobial efficacy. J Arthroplasty 2008;23(6 Suppl 1):110-4.

32. Chang Y, Chen WC, Hsieh PH, Chen DW, Lee MS, Shih $\mathrm{HN}$, et al. In vitro activities of daptomycin-, vancomycin-, and teicoplanin-loaded polymethylmethacrylate against methicillin-susceptible, methicillin-resistant, and vancomycin-intermediate strains of Staphylococcus aureus. Antimicrob Agents Chemother 2011;55:5480-4.

33. Miola M, Bistolfi A, Valsania MC, Bianco C, Fucale G, Verné E. Antibiotic-loaded acrylic bone cements: an in vitro study on the release mechanism and its efficacy. Mater Sci Eng C Mater Biol Appl 2013;33:3025-32.

34. Klekamp J, Dawson JM, Haas DW, DeBoer D, Christie M. The use of vancomycin and tobramycin in acrylic bone cement: biomechanical effects and elution kinetics for use in joint arthroplasty. J Arthroplasty 1999;14:339-46. 